\title{
New hybrid materials with porphyrin-ferrocene and porphyrin-pyrene covalently linked to single-walled carbon nanotubes.
}

\author{
Solon P. Economopoulos, ${ }^{a}$ Angeliki Skondra, ${ }^{b}$ Kalliopi Ladomenou, ${ }^{b}$ Nikolaos Karousis, ${ }^{a}$ Georgios \\ Charalambidis, ${ }^{b}$ Athanassios G. Coutsolelos ${ }^{* b}$ and Nikos Tagmatarchis ${ }^{* a}$ \\ s Received (in XXX, XXX) Xth XXXXXXXXX 20XX, Accepted Xth XXXXXXXXX 20XX \\ DOI: $10.1039 / b 000000 x$
}

Novel porphyrin derivatives bearing additional pyrene or ferrocene units as light harvesting antenna systems were synthesized and fully characterized. Following a covalent functionalization approach for single-walled carbon nanotubes (SWCNTs), stable SWCNT suspensions in common organic solvents 10 were produced. Subsequently, the resulting porphyrin-pyrene and porphyrin-ferrocene dyads were incorporated onto the nanotubes' backbone yielding donor-donor-acceptor hybrids. The resulting hybrid materials were soluble in common organic solvents and were characterized using micro-Raman, ATR-IR, UV-Vis and photoluminescence spectroscopy, transmission electron microscopy, thermogravimetric analysis and electrochemistry. Photoluminescence quenching of the porphyrin emission in both hybrid 15 materials was detected thus suggesting the potentiality of these materials in photoelectrochemical cells.

\section{Introduction}

The last couple of decades a new interdisciplinary area in material science and applications has emerged. Various unique structures of nanomaterials, such as fullerenes, carbon nanotubes

20 (CNTs) and graphene, possess remarkable mechanical, thermal, and optical properties making them suitable for an array of technological applications in electronics, advanced materials, and nanomedicine. Their inherent desirable properties are only enriched through the process of chemical modification and 25 improving upon solubility and processability, but also offering the opportunity to tune the physical properties

Single wall carbon nanotubes (SWCNTs) exhibit interesting electronic properties ${ }^{1}$ rivalling the ones of buckminsterfullerene, while maintaining excellent mechanical properties. Furthermore, ${ }_{30}$ SWCNTs exhibit very high tensile strength and excellent thermal and electrical conductivity, while their high aspect ratio and nanoscale size make them a great candidate in diverse nanotechnology applications. ${ }^{2}$ The main drawback of CNTs, that is the poor solubility properties, is countered by chemical 35 functionalization. Therefore, synthetic efforts have focused on the functionalization of $\mathrm{SWCNTs}^{3}$ thus affording materials soluble in common organic solvents. Solubilizing CNTs will permit their easier incorporation in organic electronic devices with low-cost widespread processing techniques. Modern synthetic efforts have 40 focused on coupling moieties with electro- or photo-active properties onto SWCNTs affording donor acceptor architectures with interesting optoelectronic properties. ${ }^{4,5}$ This motif has also been realized for carbon nanohorns $(\mathrm{CNHs})^{6,7}$ and lately graphene sheets. $^{8,9}$

45 The idea of adding a second light harvesting moiety to the solar cell active layer is not novel and several synthetic efforts have been made towards the realization of this concept in fullerenes giving rise to triads. ${ }^{10,11}$ Careful design or selection of the chromophore(s) to include multiple photon absorbers in a so single system is an intriguing approach that opens up new pathways towards developing an efficient solar absorber extending to the near-IR region. ${ }^{12}$ On the other hand as a standalone active moiety the realization of donor-acceptor-donor architectures can prove extremely efficient in various fields 55 ranging from sensors ${ }^{13}$ to optoelectronics. ${ }^{14-17}$

Porphyrins, being the basis for chlorophyll, the natural photon absorbing moiety of the plants, are an excellent candidate for organic solar cells, providing light harvesting properties as well as being bulky molecules that can aid in solubilization. ${ }_{60}$ Fullerene-porphyrin structures have been studied extensively as they provide a stable platform for studying the properties of donor-acceptor hybrids. ${ }^{18}$ The resulting molecule can act as a stand-alone active system providing electron donating properties, owed to the porphyrin moiety and electron accepting properties, ${ }_{65}$ due to the carbon nanostructure. This has been attempted preliminary on a non-covalent basis, ${ }^{19}$ but there are also many examples of porphyrin-SWCNT nanohybrids linked with covalent bonding. ${ }^{5,20,21}$ The addition of a second light-harvesting moiety that acts synergistically with the porphyrin will give rise 70 to donor-donor-acceptor structures. In an example of this type of structures the electron donor ferrocene $(\mathrm{Fc})$ was used in porphyrin and fullerene systems to construct multicomponent systems. $^{22}$ In a very recent example a covalent linked Fcporphyrin-SWCNT hybrid material has been synthesized via 75 amidation reaction between an oxidized SWCNTs and an aminoterminated porphyrin moiety carrying a $\mathrm{Fc}$ unit. ${ }^{23}$

Herein, we present the covalent conjugation of porphyrinferrocene and porphyrin-pyrene moieties onto pre-modified SWCNTs. The newly formed SWCNT-based hybrids were found 


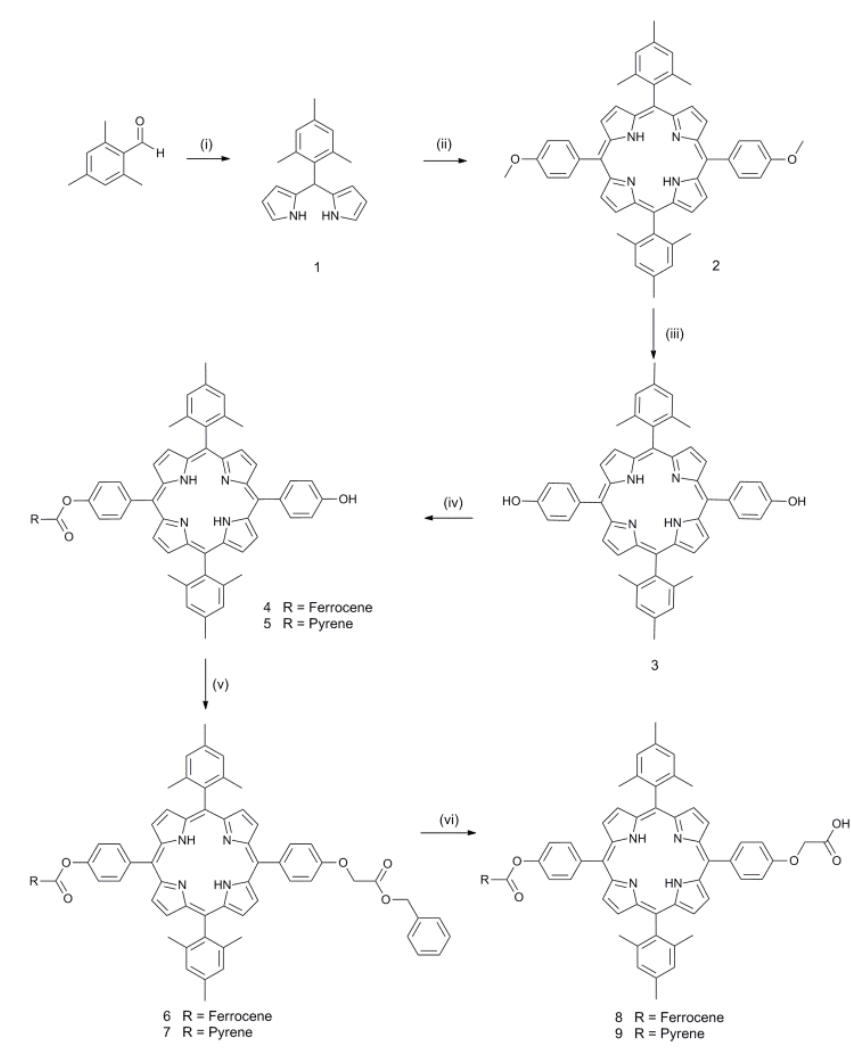

Scheme 1 Synthetic procedure for the preparation of porphyrin derivatives 8 and 9. (i) pyrrole, TFA; (ii) 4-methoxybenzaldehyde, TFA, DDQ, $\mathrm{CH}_{2} \mathrm{Cl}_{2}$; (iii) $\mathrm{BBr}_{3}, \mathrm{CH}_{2} \mathrm{Cl}_{2}$ then $\mathrm{CH}_{3} \mathrm{OH}, \mathrm{H}_{2} \mathrm{O}$; (iv) $\mathrm{Et}_{3} \mathrm{~N}$, ferrocene5 1-carbonyl chloride for $\mathbf{4}$ or pyrene-1-carbonyl chloride for 5; (v) benzyl 2-bromoacetate, $\mathrm{K}_{2} \mathrm{CO}_{3}$, DMF; (vi) $\mathrm{H}_{2}, 10 \% \mathrm{Pd} / \mathrm{C}$, THF.

soluble in common organic solvents and fully characterized with complementary spectroscopic, thermal and microscopy techniques, while their photochemical and electrochemical 10 properties were also evaluated.

\section{Experimental}

2.1. Synthesis of 5-(4-(carboxymethoxy)phenyl)-15-(4(ferrocene-2-carbonyloxy)phenyl)-10,20-bis (2,4,6trimethylphenyl)porphyrin 8.

15 A solution of porphyrin $6(15 \mathrm{mg}, 0.01 \mathrm{mmol})$ and $10 \% \mathrm{Pd} / \mathrm{C}(5$ $\mathrm{mg}, 0.05 \mathrm{mmol})$ in THF $(5 \mathrm{~mL})$ was stirred under $\mathrm{H}_{2}$ at room temperature overnight. Then the mixture was filtered on a pad of celite and the solid washed first with THF $(5 \mathrm{~mL})$ and then with $\mathrm{MeOH}(5 \mathrm{~mL})$. The solvents were removed from the filtrate and 20 the resulting solid was purified by column chromatography (1-20 $\%$ methanol in dichloromethane). The desired product was obtained using $20 \% \mathrm{MeOH}$ in $\mathrm{CH}_{2} \mathrm{Cl}_{2}$ to give 8 as a purple solid (9.5 mg, $95 \%) .{ }^{1} \mathrm{H}$ NMR (500 MHz, $\left.\mathrm{CDCl}_{3}\right): \delta 8.87(\mathrm{~d} \mathrm{br}, 2 \mathrm{H})$, $8.80(\mathrm{~d} \mathrm{br}, 2 \mathrm{H}), 8.71(\mathrm{~m}, 4 \mathrm{H}), 8.27(\mathrm{~d}, J=6.0 \mathrm{~Hz}, 2 \mathrm{H}), 8.16(\mathrm{~d}, J$ $\left.{ }_{25}=5.0 \mathrm{~Hz}, 2 \mathrm{H}\right), 7.59(\mathrm{~d}, J=7.5 \mathrm{~Hz}, 2 \mathrm{H}), 7.29\left(\mathrm{~s} \mathrm{br}, 6 \mathrm{H}, \mathrm{H}_{3}\right), 5.1$ (s, 2H), 4.92 (s br, 2H), 4.60 (s, 2H), 4.43 (s, 5H), 2.63 (s, 6H), $1.85(\mathrm{~s}, 12 \mathrm{H}),-2.65(\mathrm{~s}, 2 \mathrm{H}) ;{ }^{13} \mathrm{C} \mathrm{NMR}\left(75 \mathrm{MHz}, \mathrm{CDCl}_{3}\right): \delta 171.6$, $170.6,157.3,150.8,139.4,138.4,137.8,135.7,135.4,131.5$, $130.2,127.8,120.1,118.4,113.0,72.1,70.8,70.1,65.2,21.6$, 30 21.5; UV/vis $\left(\mathrm{CH}_{2} \mathrm{Cl}_{2}\right) \lambda_{\max }, \mathrm{nm}\left(\varepsilon, \mathrm{mM}^{-1} \mathrm{~cm}^{-1}\right) 419$ (441.2), 447 (23.1), 515 (16.9), 550 (6.7), 591 (4.8), 647 (3.7); HRMS (MALDI-TOF) calcd for $\mathrm{C}_{63} \mathrm{H}_{53} \mathrm{FeN}_{4} \mathrm{O}_{5}[\mathrm{M}+\mathrm{H}]^{+}$1001.3365, found 1001.3372 .

2.2. Synthesis of 5-(4-(carboxymethoxy)phenyl)-15-(435 (pyrene-1-carbonyloxy)phenyl)-10,20-bis $(2,4,6-$ trimethylphenyl)porphyrin 9.

A solution of porphyrin $7(25 \mathrm{mg}, 0.02 \mathrm{mmol})$ and $10 \% \mathrm{Pd} / \mathrm{C}(8$ $\mathrm{mg}, 0.08 \mathrm{mmol})$ in THF $(5 \mathrm{~mL})$ was stirred under $\mathrm{H}_{2}$ at room temperature overnight. Then the mixture was filtered on a pad of 40 celite and the solid washed first with THF $(5 \mathrm{~mL})$ and then with $\mathrm{MeOH}(5 \mathrm{~mL})$. The solvents were removed from the filtrate and the resulting solid was purified by column chromatography $\left(\mathrm{CH}_{2} \mathrm{Cl}_{2} / \mathrm{MeOH}\right.$ 7:3). The desired product was obtained using $\mathrm{CH}_{2} \mathrm{Cl}_{2} / \mathrm{MeOH}$ 7:3 to give 9 as a purple solid (19 mg, $\left.93 \%\right) .{ }^{1} \mathrm{H}$ 45 $\mathrm{NMR}\left(300 \mathrm{MHz}, \mathrm{CDCl}_{3}\right): \delta 9.57(\mathrm{~m}, 1 \mathrm{H}), 9.10(\mathrm{~m}, 1 \mathrm{H}), 8.92(\mathrm{~d}$ br, 2H), $8.80(\mathrm{~d} \mathrm{br}, 2 \mathrm{H}), 8.73(\mathrm{~m}, 4 \mathrm{H}), 8.37-8.14(\mathrm{~m}, 11 \mathrm{H}), 7.78$ (d, $J=7.8 \mathrm{~Hz}, 2 \mathrm{H}), 7.30$ (s, 4H), 7.26 (s br, 2H), 2.64 (s, 6H), $1.87(\mathrm{~s}, 12 \mathrm{H}),-2.55(\mathrm{~s}, 2 \mathrm{H}) ;{ }^{13} \mathrm{C} \mathrm{NMR}\left(75 \mathrm{MHz}, \mathrm{CDCl}_{3}\right): \delta 171.2$, $166.5,157.4,151.2,140.4,139.5,138.4,137.9,135.6,135.2$, so $132.2,131.1,130.4,130.3,129.2,128.5,127.9,127.3,126.6$, 125.1, 124.9, 124.3, 122.0, 120.3, 118.7, 114.4, 113.1, 65.1, 21.7, 21.5; UV/vis $\left(\mathrm{CH}_{2} \mathrm{Cl}_{2}\right) \lambda_{\max }, \mathrm{nm}\left(\varepsilon, \mathrm{mM}^{-1} \mathrm{~cm}^{-1}\right) 284(31.5), 357$ (32.0), 419 (349.3), 515 (15.8), 550 (6.9), 591 (5.1), 647 (3.9); HRMS (MALDI-TOF) calcd for $\mathrm{C}_{69} \mathrm{H}_{53} \mathrm{~N}_{4} \mathrm{O}_{5}[\mathrm{M}+\mathrm{H}]^{+}$1017.4016, 5 found 1017.4022.

\subsection{Synthesis of hybrid materials 11 and 12 .}

A solution of ferrocene-porphyrin 8 or pyrene-porphyrin 9, 1-(3dimethylaminopropyl)-3-ethylcarbodiimide hydrochloride (5 equiv.) and 1-hydroxy-benzotriazole (5 equiv.) in chloroform (10 $60 \mathrm{~mL}$ ) was stirred for $30 \mathrm{~min}$. at room temperature and then was added to a triethylamine-neutralized solution of ammoniumfunctionalized SWCNTs $\mathbf{1 0}^{24}(20 \mathrm{mg})$ in chloroform $(15 \mathrm{~mL})$. The reaction mixture was stirred at room temperature for $48 \mathrm{~h}$ and then was filtered through PTFE membrane filter (pore size $\left.{ }_{65} 0.2 \mu \mathrm{m}\right)$ and washed with dichloromethane $(100 \mathrm{~mL})$, methanol $(100 \mathrm{~mL})$ and diethylether $(50 \mathrm{~mL})$.

\section{Results and Discussion}

The synthesis of ferrocene-porphyrin 8 and pyrene-porphyrin 9 - abbreviated as $\mathrm{H}_{2} \mathrm{P}-\mathrm{Fc}$ and $\mathrm{H}_{2} \mathrm{P}-$ pyr, respectively - is 70 schematically shown in Scheme 1 . Briefly, acid-catalyzed reaction of 4-methoxybenzaldehyde and 2,2'-(2,4,6trimethylphenylmethylene)bis(1H-pyrrole) $\mathbf{1}$, followed by demethylation in the presence of boron tribromide, afforded 5,15bis(4-hydroxyphenyl)-10,20-bis(2,4,6-trimethylphenyl)porphyrin 75 3. At this point it is important to note that the sterically demanding 2,4,6-trimethylphenyl moiety present as a substituent of the bis(1H-pyrrole)methane was deliberately chosen due to its ability to afford trans-meso substituted porphyrins without scrambling, thus avoiding the formation of a complicated mixture 80 of porphyrins. Then, selective condensation reaction of porphyrin 3 with either ferrocene or pyrene carbonyl chloride yielded mono-substituted porphyrins $\mathbf{4}$ and $\mathbf{5}$, respectively, possessing a free hydroxyl group at the meso-position. The latter was subsequently coupled with benzyl bromo acetate to result ${ }_{85}$ protected analogues 6 and 7. Successful cleavage of the benzyl group after catalytic hydrogenation afforded the final porphyrin products bearing ferrocene for $\mathbf{8}$ and pyrene groups for $\mathbf{9}$, 


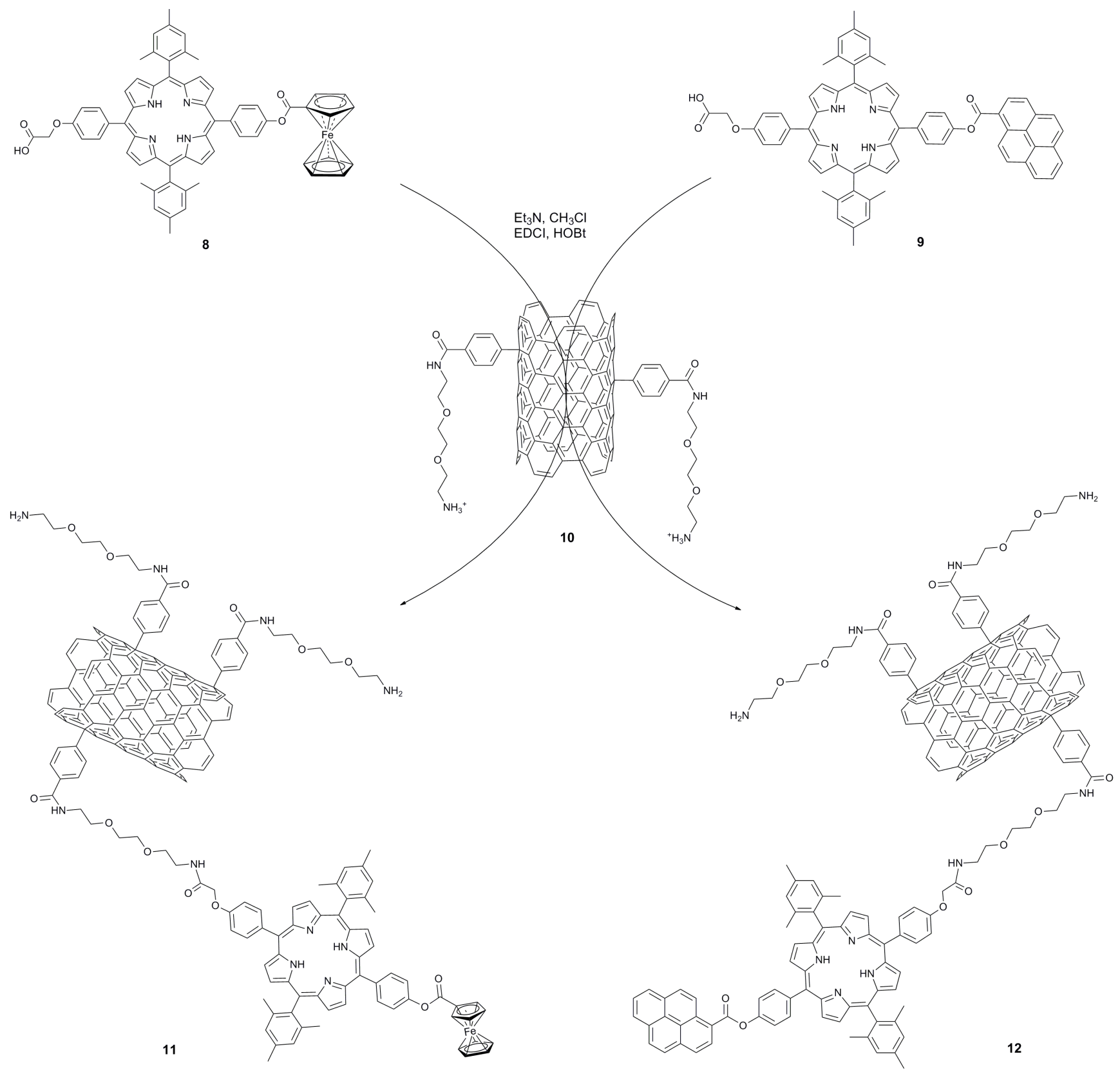

Scheme 2 Synthetic procedure for the preparation of the SWCNT- $\left(\mathrm{H}_{2} \mathrm{P}-\mathrm{Fc}\right) 11$ and SWCNT- $\left(\mathrm{H}_{2} \mathrm{P}-\right.$ pyr $)$ hybrid materials 12

respectively. The structure of all synthesized compounds was verified by ${ }^{1} \mathrm{H}$ and ${ }^{13} \mathrm{C}$ NMR spectroscopy as well as MALDI s TOF mass spectrometry (Figs. S1-S16 in ESI†े).

In a parallel route, SWCNTs were functionalized by the widely applied methodology of in-situ generated aryl diazonium salts addition. ${ }^{25}$ In this context, aryl units possessing at para-position a polar ethylene glycol chain terminating with a Boc amino10 protected group were successfully introduced onto the skeleton of SWCNTs. Then, under acidic conditions, the free amino-units were liberated and porphyrin derivatives $\mathbf{8}$ and $\mathbf{9}$ were covalently attached to the amino-modified SWCNTs $\mathbf{1 0}$, by a typical condensation reaction, according to Scheme 2. The hybrid 15 materials $\mathbf{1 1}$ and $\mathbf{1 2}$ form stable dispersions in a range of polar solvents like dichloromethane, methanol and $N, N$ dimethylformamide, thus allowing their spectroscopic characterization and to perform studies of their properties in solution.

20 The morphological characterization of SWCNT- $\left(\mathrm{H}_{2} \mathrm{P}-\mathrm{Fc}\right) \mathbf{1 1}$ 


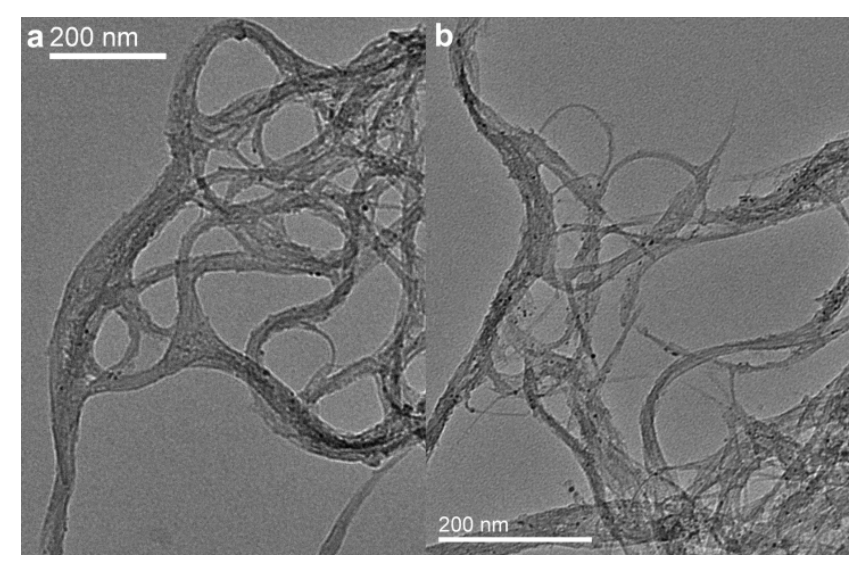

Fig. 1 Representative TEM images of a) SWCNT- $\left(\mathrm{H}_{2} \mathrm{P}-\mathrm{Fc}\right) \mathbf{1 1}$ and b) SWCNT- $\left(\mathrm{H}_{2} \mathrm{P}-\right.$ pyr $) 12$ hybrid materials.

and SWCNT-( $\mathrm{H}_{2} \mathrm{P}$-pyr $) 12$ was achieved by transmission 5 electron microscopy (TEM). Representative TEM images (Fig. 1) of 11 and 12 reveal the presence of small bundles $(10-90 \mathrm{~nm}$ in diameter) of SWCNTs. Moreover, no significant damage of the SWCNT backbone skeleton due to the functionalization is observed.

${ }_{10}$ Spectroscopic insight on the formation of SWCNT- $\left(\mathrm{H}_{2} \mathrm{P}-\mathrm{Fc}\right)$ 11 and SWCNT-( $\left.\mathrm{H}_{2} \mathrm{P}-\mathrm{pyr}\right) \mathbf{1 2}$ hybrid materials was delivered by vibrational spectroscopy. Attenuated-total-reflectance infra-red (ATR-IR) spectroscopy indicates the $\mathrm{C}=\mathrm{O}$ stretching vibrations due to carbonyl amides at $1640 \mathrm{~cm}^{-1}$ and carboxylic esters at $151720 \mathrm{~cm}^{-1}$, while the $\mathrm{C}-\mathrm{H}$ stretching vibrations at 2843 and 2922 $\mathrm{cm}^{-1}$ are also observed (Fig. S17 in ESI $\dagger$ ).

Raman spectroscopy provided efficient support for the successful covalent functionalization of SWCNTs. Basically the Raman spectrum of aryl functionalized SWCNTs $\mathbf{1 0}$ exhibits two 20 bands at 1336 and $1591 \mathrm{~cm}^{-1}$. The former, D-band, is assigned to $\mathrm{sp}^{3}$-bonded carbon atoms and the latter, G-band, to $\mathrm{sp}^{2}$ ones. For the aryl-functionalized SWCNT material the Raman spectrum shows an increased D-band (Fig. S18 in ESI $\dagger$ ), while the $\mathrm{I}_{\mathrm{D}} / \mathrm{I}_{\mathrm{G}}$ ratio found enhanced as compared with that for intact SWCNTs

${ }_{25}\left(\mathrm{I}_{\mathrm{D}} / \mathrm{I}_{\mathrm{G}}=0.28\right.$ vs $\left.\mathrm{I}_{\mathrm{D}} / \mathrm{I}_{\mathrm{G}}=0.12\right)$. Thus, that observation reflects the presence of $\mathrm{sp}^{3}$-hybridized carbons due to the attachment of the aryl moieties onto SWCNTs. However, the conjugation of porphyrin moieties, in the form of $\mathrm{H}_{2} \mathrm{P}-\mathrm{Fc} 8$ and $\mathrm{H}_{2} \mathrm{P}$-pyr $\mathbf{9}$, onto the already modified SWCNTs $\mathbf{1 0}$ does not significantly change 30 the nature of the Raman spectrum (Fig. S19 in ESI $\dagger$ ), as no further disruption on the carbon skeleton of SWCNTs occurs.

Thermogravimetric analysis (TGA) is a powerful tool to determine the degree of functionalization. Pristine SWCNTs are thermally intact and stable up to at least $800{ }^{\circ} \mathrm{C}$ under nitrogen 35 atmosphere. Ammonium-functionalized SWCNTs $\mathbf{1 0}$ show a weight loss of $24 \%$, occurring in the temperature range of 200 $580{ }^{\circ} \mathrm{C}$, attributed to the decomposition of the aryl units grafted onto the surface of the nanotubes (Fig. 2). Taking into account the above value, the degree of functionalization was calculated 40 and found to be 1 aryl ethylene glycol side chain per 73 carbon atoms of SWCNT material. TGA analysis for $\mathrm{H}_{2} \mathrm{P}-\mathrm{Fc}$ functionalized SWCNTs 11 and $\mathrm{H}_{2} \mathrm{P}$-pyr functionalized SWCNTs 12, performed under same conditions, showed a weight loss of $27 \%$ and $30 \%$, respectively, up to $550{ }^{\circ} \mathrm{C}$, corresponding to the 45 decomposition of the total organic matter grafted onto the surface

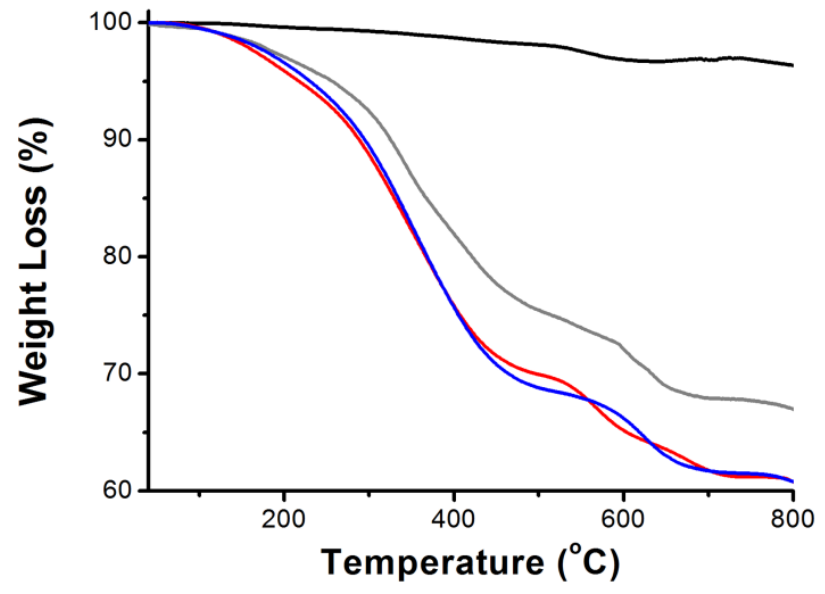

Fig. 2 TGA graphs of pristine SWCNTs (black), ammoniumfunctionalized SWCNTs 10 (gray), SWCNT- $\left(\mathrm{H}_{2} \mathrm{P}-\mathrm{Fc}\right) \mathbf{1 1}$ (red) and SWCNT-( $\mathrm{H}_{2} \mathrm{P}$-pyr) 12 (blue), obtained under nitrogen.

${ }_{50}$ of the nanotubes framework. Based on that, it is evaluated that 1 $\mathrm{H}_{2} \mathrm{P}-\mathrm{Fc}$ based organic moiety for every 267 carbon atoms is present onto the functionalized SWCNTs 11 and $1 \mathrm{H}_{2} \mathrm{P}-$ pyr based organic moiety for every 239 carbon atoms for hybrid material 12. By simply correlating those values with the one mentioned 5 above for the ammonium-functionalized SWCNTs 10, it is understood that approximately only one out of four $-\mathrm{NH}_{2}$ units were condensed with the appropriate $\mathrm{H}_{2} \mathrm{P}-\mathrm{Fc}$ and $\mathrm{H}_{2} \mathrm{P}$-pyr moiety. Nevertheless, the latter can be rationalized when considering steric hindrance phenomena introduced by the large volume ${ }_{60}$ modified porphyrins occupy onto the SWCNT surface. The weight loss above $600{ }^{\circ} \mathrm{C}$ is attributed to decomposition of miscellaneous forms of disordered carbon ${ }^{26}$ and due to the defects introduced on the carbon backbone through the functionalization procedure.

${ }_{65}$ Due to the long chain that can act as spacer, hybrid materials 11 and 12 can provide interesting optical properties as recently demonstrated on graphene donor-spacer-acceptor hybrids. ${ }^{27}$ As hybrid materials $\mathbf{1 1}$ and $\mathbf{1 2}$ show enhanced solubility in DMF and since optically active moieties have been attached to the ${ }_{70}$ SWCNTs' backbone, absorption and photoluminescence spectroscopy can be applied for evaluating the optical properties of the synthesized materials. In Fig. 3 the absorption spectra of SWCNT- $\left(\mathrm{H}_{2} \mathrm{P}-\mathrm{Fc}\right) \quad \mathbf{1 1}$ and SWCNT- $\left(\mathrm{H}_{2} \mathrm{P}-\mathrm{pyr}\right) \mathbf{1 2}$ hybrid materials are compared with those ones derived from the 75 unbound $\mathrm{H}_{2} \mathrm{P}-\mathrm{Fc} 8$ and $\mathrm{H}_{2} \mathrm{P}$-pyr 9. In the electronic absorption spectrum of 8 the predominant Soret band at $420 \mathrm{~nm}$ as well as the Q bands at 516, 551 and 594 and $650 \mathrm{~nm}$ are clearly observed (Fig. 3a). Hybrid material $\mathbf{1 1}$ shows a continuous absorption in the UV-Vis spectrum common for SWCNTs with a clear 80 shoulder at $424 \mathrm{~nm}$, corresponding to the Soret band, red-shifted by $4 \mathrm{~nm}$ as compared with that of unbound $\mathbf{8}$. Similarly, the $\mathrm{UV}-\mathrm{Vis}$ spectrum of $\mathrm{H}_{2} \mathrm{P}$-pyr 9 shows the characteristic Soret band at $419 \mathrm{~nm}$ as well as the Q bands at 515, 550, 592 and 648 $\mathrm{nm}$, while in the corresponding UV-Vis spectrum of ${ }_{85} \mathrm{SWCNT}-\left(\mathrm{H}_{2} \mathrm{P}-\right.$ pyr $) 12$ a clear shoulder at $422 \mathrm{~nm}$, corresponding to the Soret band, red-shifted by $2 \mathrm{~nm}$ as compared with that of unbound 9 is found (Fig. 3b). These observations are in line with both the success of the linkage of $\mathrm{H}_{2} \mathrm{P}-\mathrm{Fc} \mathbf{8}$ and $\mathrm{H}_{2} \mathrm{P}-$ pyr $\mathbf{9}$, respectively, to aryl-modified SWCNTs $\mathbf{1 0}$ and more importantly 

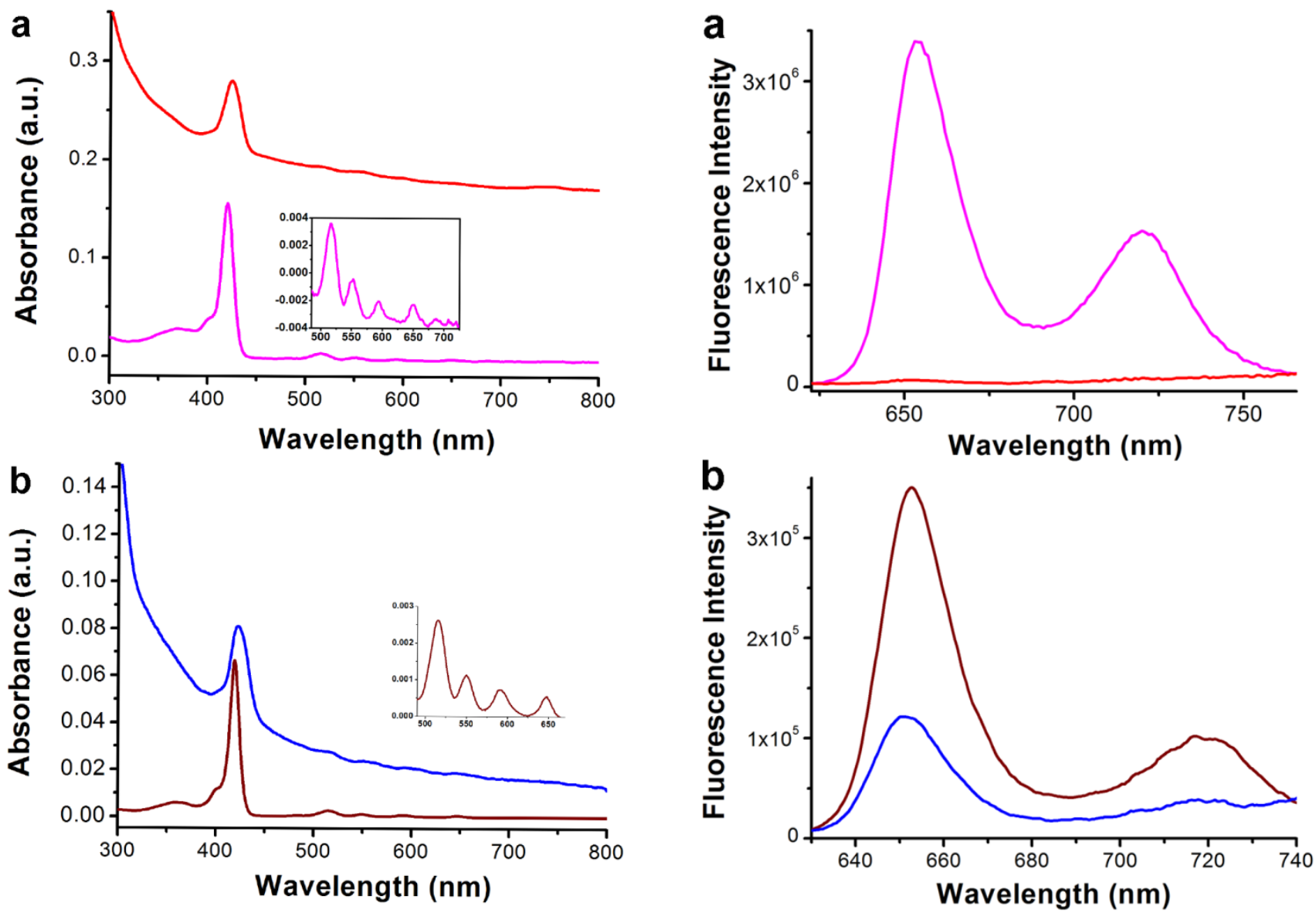

Fig. 3 UV-Vis absorption spectra of a) $\mathrm{H}_{2} \mathrm{P}-\mathrm{Fc} 8$ (magenta) and SWCNT-( $\left.\mathrm{H}_{2} \mathrm{P}-\mathrm{Fc}\right) 11$ (red), and b) $\mathrm{H}_{2} \mathrm{P}$-pyr 9 (brown) and SWCNT-( $\mathrm{H}_{2} \mathrm{P}-$ pyr) 12 (blue).

5 to ground state electronic interactions between SWCNTs and $\mathrm{H}_{2} \mathrm{P}-\mathrm{Fc}$ in the SWCNT- $\left(\mathrm{H}_{2} \mathrm{P}-\mathrm{Fc}\right) \mathbf{1 1}$ and $\mathrm{H}_{2} \mathrm{P}-\mathrm{pyr}$ in the SWCNT- $\left(\mathrm{H}_{2} \mathrm{P}-\right.$ pyr $) 12$ hybrid materials, respectively. However, weak inter-porphyrin interactions, most likely between porphyrins located on the same nanotube, should be also 10 considered and taken into account. Notably, such results are in agreement with earlier studies based on other hybrid materials composed of different porphyrins bonded to SWCNTs, CNHs and graphene. ${ }^{7,28,29}$

Insight on the electronic interplay between $\mathrm{H}_{2} \mathrm{P}-\mathrm{Fc} 8$ and $\mathrm{H}_{2} \mathrm{P}-$ 15 pyr 9, respectively, and SWCNTs in the excited state of hybrids $\mathbf{1 1}$ and $\mathbf{1 2}$ is derived from photoluminescence studies. Upon excitation at $420 \mathrm{~nm}$, the strong fluorescence emission of porphyrin 8 at $653 \mathrm{~nm}$ was significantly quenched by the presence of SWCNTs in the SWCNT- $\left(\mathrm{H}_{2} \mathrm{P}-\mathrm{Fc}\right)$ 11, when 20 measurements performed with matching absorption of $\mathrm{H}_{2} \mathrm{P}-\mathrm{Fc}$ at the excitation wavelength (Fig. 4a). The latter observation is indicative of electronic interactions between the singlet excited state of ${ }^{1}\left(\mathrm{H}_{2} \mathrm{P}-\mathrm{Fc}\right)^{*}$ and SWCNTs, thus suggesting that photoilluminated $\mathrm{H}_{2} \mathrm{P}-\mathrm{Fc}$ can transport electrons to the electron 25 accepting SWCNTs, in hybrid material 11. A similar phenomenon was observed for SWCNT- $\left(\mathrm{H}_{2} \mathrm{P}-\mathrm{pyr}\right)$ hybrid material 12 (Fig. 4b), namely, quenching of the characteristic strong emission of $\mathrm{H}_{2} \mathrm{P}-$ pyr at $653 \mathrm{~nm}$, when excited at $420 \mathrm{~nm}$.

Fig. 4 Photoluminescence spectra of a) $\mathrm{H}_{2} \mathrm{P}-\mathrm{Fc} 8$ (magenta) and SWCNT-( $\left.\mathrm{H}_{2} \mathrm{P}-\mathrm{Fc}\right) 11$ (red), and b) $\mathrm{H}_{2} \mathrm{P}$-pyr 9 (brown) and SWCNT- $\left(\mathrm{H}_{2} \mathrm{P}-\right.$ pyr) 12 (blue), upon excitation at $420 \mathrm{~nm}$.

Finally, the energetics of the photoinduced process in SWCNT- $\left(\mathrm{H}_{2} \mathrm{P}-\mathrm{Fc}\right) \quad 11$ and SWCNT- $\left(\mathrm{H}_{2} \mathrm{P}-\mathrm{pyr}\right) \mathbf{1 2}$ hybrid 35 materials were evaluated by determining the corresponding redox potentials. Electrochemistry studies were performed by differential pulse voltammetry (DPV) in dry DMF, with [ $(n-$ $\mathrm{Bu})_{4} \mathrm{NPF}_{6}$ ] as electrolyte. The materials were studied using a standard three electrode cell using Pt disc $1.6 \mathrm{~mm}$ diameter as a 40 working electrode, $\mathrm{Pt}$ mesh as a counter electrode and Pt wire as a pseudo reference electrode. All voltammograms were calibrated vs $\mathrm{Fc} / \mathrm{Fc}^{+}$. When examining $\mathrm{H}_{2} \mathrm{P}-\mathrm{Fc} 8$ by DPV (reduction run), a clear one-electron reduction was observed at $-1.62 \mathrm{~V}$ attributed to the porphyrin moiety as no appreciable signal from the ferrocene 45 is expected at that potential (Fig. 5a). The same reduction peak slightly shifted by $50 \mathrm{mV}$ towards positive potentials was also observed in the SWCNT- $\left(\mathrm{H}_{2} \mathrm{P}-\mathrm{Fc}\right)$ hybrid material 11 along with a broad weak reduction at $-0.50 \mathrm{~V}$ attributed to the SWCNTs reduction. ${ }^{30-34}$ When scanning in positive potentials, 8 shows a 50 reversible oxidation at $0.24 \mathrm{~V}$ characteristic of the Fc moiety, and a very broad signal with peaks around 0.63 and $0.80 \mathrm{~V}$, owed to the presence of the porphyrin moiety. These three peaks are also present in the hybrid material 11, but considerably lower in intensity. The peak assigned to the Fc moiety also has been 55 shifted anodically by almost $180 \mathrm{mV}$ denoting electronic interplay in the hybrid. The peaks assigned to the porphyrin moiety, remain unshifted in hybrid material 11. 

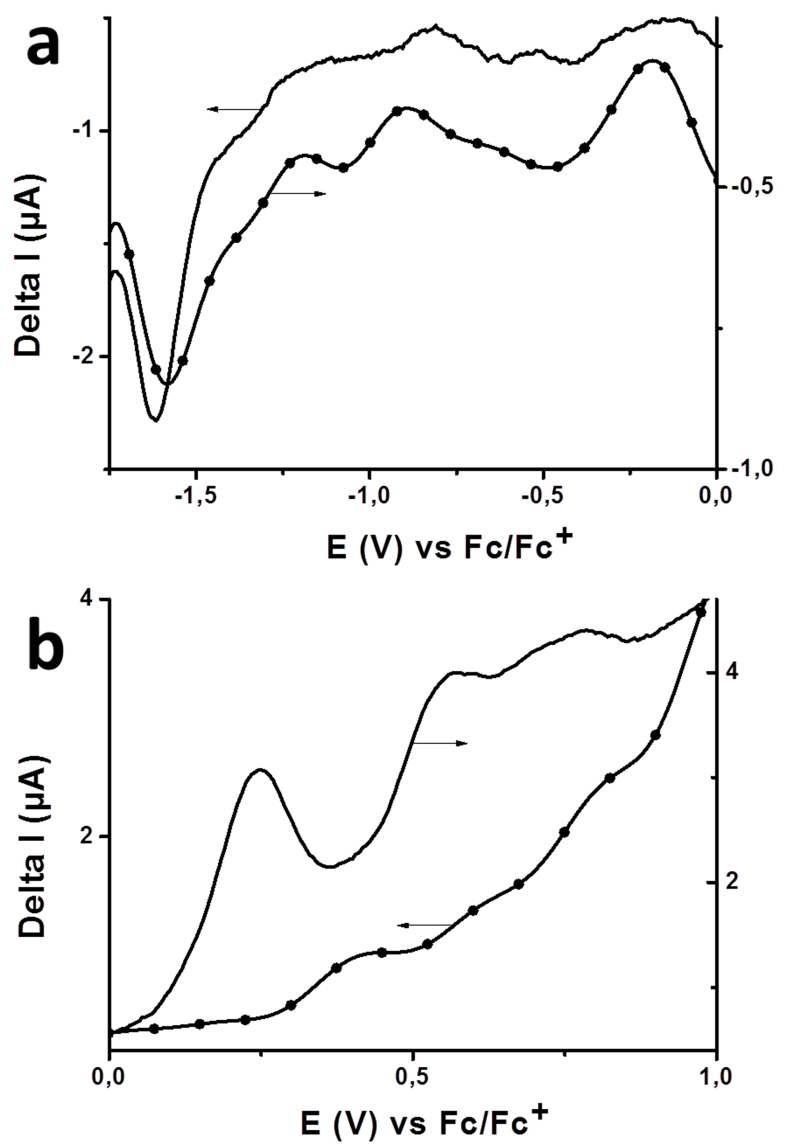

Fig. 5 Differential pulse voltammograms of $\mathrm{H}_{2} \mathrm{P}-\mathrm{Fc} \mathbf{8}$ (solid line) and SWCNT- $\left(\mathrm{H}_{2} \mathrm{P}-\mathrm{Fc}\right) \mathbf{1 1}(-\bullet-)$, a) reduction, and b) oxidation runs.

In Fig. 6 the DPV scans - reduction and oxidation runs - of 5 materials 9 and $\mathbf{1 2}$ are presented. A pair of reduction processes takes place at negative potentials in 9 with peaks at -0.163 and $0.136 \mathrm{~V}$. The former is a reduction also present in $\mathbf{8}$ so it is logical to assign this process to the reduction of the porphyrin moiety. The latter peak can be attributed to the pyrene moiety.

${ }_{10}$ When examining hybrid 12, however, these processes are not observable but a rather strong signal at $-1.25 \mathrm{~V}$ is present. This process, as was the case with hybrid 11, is anodically shifted compared to 9. A weak broad peak at $-0.55 \mathrm{~V}$ attributed to the SWCNTs reduction is also present in the DPV of $12 .{ }^{30-34}$ In the 15 oxidation run of the DPV a single process is present in both the dyad and the triad.

Table 1 Electrochemical data of the dyads and the triads synthesized.

\begin{tabular}{|c|c|c|c|c|c|}
\hline Materials & $\begin{array}{l}\mathbf{E}^{\text {ox }} \\
(\mathbf{V})\end{array}$ & $\begin{array}{c}\mathbf{E}_{\text {номо }} \\
(\mathrm{eV})\end{array}$ & $\begin{array}{l}\mathbf{E}^{\mathrm{red}} \\
(\mathbf{V})\end{array}$ & $\begin{array}{c}\text { E Lumo } \\
(\mathrm{eV})\end{array}$ & $\begin{array}{c}\mathbf{E}_{\mathrm{g}}^{\text {echem }} \\
(\mathrm{eV})\end{array}$ \\
\hline $\begin{array}{l}\mathrm{H}_{2} \mathrm{P}-\mathrm{Fc} \\
\mathbf{8}\end{array}$ & $\begin{array}{l}0.24 \\
0.63 \\
0.80\end{array}$ & $\begin{array}{l}5.34 \\
5.73\end{array}$ & -1.62 & 3.48 & 1.86 \\
\hline $\begin{array}{l}\mathrm{H}_{2} \mathrm{P}-\mathrm{pyr} \\
\mathbf{9}\end{array}$ & 0.57 & 5.67 & $\begin{array}{l}-1.63 \\
-1.36\end{array}$ & 3.74 & -1.93 \\
\hline $\begin{array}{c}\text { SWCNT- }\left(\mathrm{H}_{2} \mathrm{P}-\mathrm{Fc}\right) \\
\mathbf{1 1}\end{array}$ & $\begin{array}{l}0.42 \\
0.62 \\
0.81\end{array}$ & & $\begin{array}{l}-1.57 \\
-0.50\end{array}$ & & \\
\hline $\begin{array}{c}\text { SWCNT- }\left(\mathrm{H}_{2} \mathrm{P}-\mathrm{pyr}\right) \\
\mathbf{1 2}\end{array}$ & 0.59 & & $\begin{array}{l}-1.25 \\
-0.55\end{array}$ & & \\
\hline
\end{tabular}
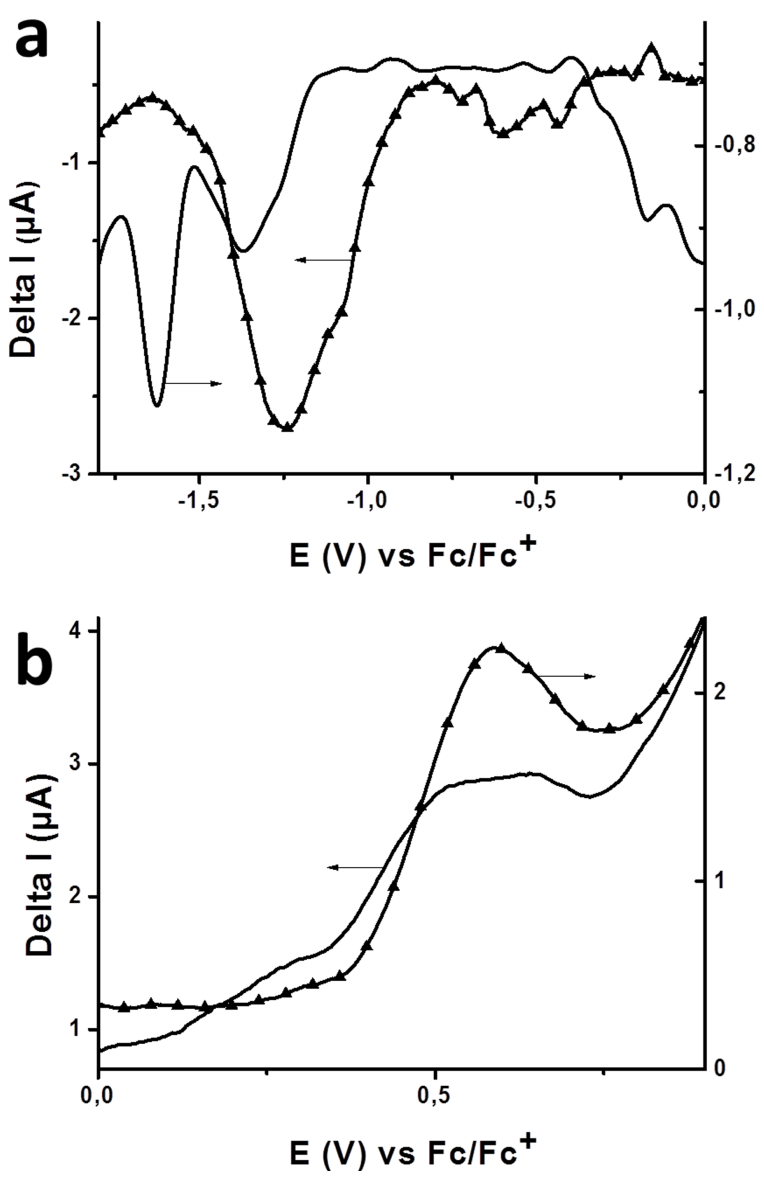

Fig. 6 Differential pulse voltammograms of $\mathrm{H}_{2} \mathrm{P}-$ pyr 9 (solid line) and SWCNT- $\left(\mathrm{H}_{2} \mathrm{P}-\right.$ pyr $) 12(-\boldsymbol{\Delta}-)$, a) reduction, and b) oxidation runs.

A very broad peak, centered at around $0.57 \mathrm{~V}$ is observed in the case of 9 and a basically unshifted peak at 0.59 but considerably ${ }_{25}$ lower in is observed in the case of hybrid $\mathbf{1 2}$. Hence, the LUMO energy level of 9 is estimated at $3.74 \mathrm{eV}$, while the HOMO level is found at $5.67 \mathrm{eV}$. Collectively, all redox data are shown in Table 1.

\section{Conclusions}

30 Two SWCNT-based triads were synthesized and characterized. Porphyrin-ferrocene and porphyrin-pyrene functionalized SWCNTs hybrid materials $\mathbf{1 1}$ and $\mathbf{1 2}$ were fully characterized with the aid of complementary spectroscopic, thermal and microscopy techniques. The hybrid triads formed stable 35 suspensions in common organic solvents. Photoluminescence measurements revealed the efficient quenching of the emission of photoexcited porphyrin in both SWCNT- $\left(\mathrm{H}_{2} \mathrm{P}-\mathrm{Fc}\right) \mathbf{1 1}$ and SWCNT- $\left(\mathrm{H}_{2} \mathrm{P}\right.$-pyrene $) \mathbf{1 2}$ hybrid materials suggesting that the individual components in the hybrid materials communicate each 40 other via electron and/or energy transfer processes. The synthesized materials provide proof of concept for the incorporation of multiple chromophores onto the SWCNT backbone. The careful selection of light harvesting moieties absorbing throughout the visible spectrum and communicate ${ }_{45}$ electronically via covalent attachment to an acceptor moiety such as carbon nanotubes comprise a solid basis for highly efficient solar energy conversion devices. 


\section{Acknowledgments}

N.T. acknowledges partial financial support from GSRT/E $\Pi$ ПA 2007-2013 through actions "Postdoctoral support" project

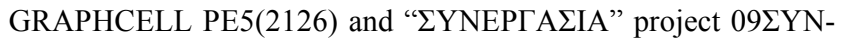
$542-691-N A N O K A T A \Lambda Y \Sigma H$ as well as from COST network MP0901 NanoTP. A.G.C. acknowledges FP7-REGPOT-2008-1, project BIOSOLENUTI No 229927 from European Commission and Heraklitos grant from Ministry of Education of Greece and GSRT.

\section{${ }_{10}$ Notes and references}

${ }^{a}$ Theoretical and Physical Chemistry Institute National Hellenic Research Foundation 48 Vassileos Constantinou Avenue, 11635 Athens, Hellas; Fax: + 30210 7273794; Tel: + 30210 7273835; E-mail: tagmatar@eie.gr

$1{ }^{b}$ Department of Chemistry, University of Crete, P O Box 1470, 71409

Heraklion Crete, Hellas; Fax: + 30 2810 545161; Tel: + 302810

545045;E-mail: coutsole@chemistry.uoc.gr

$\uparrow$ Electronic Supplementary Information (ESI) available: [Experimental details; ${ }^{1} \mathrm{H}$ and ${ }^{13} \mathrm{C}$ NMR, ATR-IR and Raman spectra]. See DOI: 20 10.1039/b000000x/

1 T. W. Odom, J.-L. Huang, P. Kim and C. M. Lieber, Nature, 1998, 391, 62 .

2 A. Vijayaraghavan, J. Mater. Chem., 2012, 22, 7083.

3 N. Karousis, N. Tagmatarchis and D. Tasis, Chem. Rev. 2010, 110, 5366.

4 H. Murakami, T. Nomura and N. Nakashima, Chem. Phys. Lett., 2003, 378, 481 .

5 Z. Guo, F. Du, D. Ren, Y. Chen, J. Zheng, Z. Liu and J. Tian, J. Mater. Chem., 2006, 16, 3021.

306 M. Vizuete, M. J. Gómez-Escalonilla, J. L. G. Fierro, A. S. D. Sandanayaka, T. Hasobe, M. Yudasaka, S. Iijima, O. Ito and F. Langa, Chem.-Eur. J., 2010, 16, 10752.

7 G. Pagona, G. E. Zervaki, A. S. D. Sandanayaka, O. Ito, G. Charalambidis, T. Hasobe, A. G. Coutsolelos and N. Tagmatarchis, J. Phys. Chem. C, 2012, 116, 9439.

8 S. P. Economopoulos, G. Rotas, Y. Miyata, H. Shinohara and N. Tagmatarchis, ACS Nano, 2010, 4, 7499.

9 T. Umeyama, J. Mihara, N. Tezuka, Y. Matano, K. Stranius, V. Chukharev, N. V. Tkachenko, H. Lemmetyinen, K. Noda, K.

40 Matsushige, T. Shishido, Z. Liu, K. Hirose-Takai, K. Suenaga and H. Imahori, Chem.-Eur. J., 2012, 18, 4250.

10 F. D'Souza, M. E. El-Khouly, S. Gadde, M. E. Zandler, A. L. McCarty, Y. Araki and O. Ito, Tetrahedron, 2006, 62, 1967.

11 Y. Matsuo, M. Maruyama, S. S. Gayathri, T. Uchida, D. M. Guldi, H.

45 Kishida, A. Nakamura and E. Nakamura, J. Am. Chem. Soc., 2009, 131, 12643.

12 V. V. Diev, K. Hanson, J. D. Zimmerman, S. R. Forrest and M. E. Thompson, Angew. Chem., Int. Ed., 2010, 49, 5523.

13 M. Song, X. Wang, W. Liu and J. Zuo, J. Colloid Interface Sci., 2010, 343, 48.

14 E. Peeters, P. A. v. Hal, S. C. J. Meskers, R. A. J. Janssen and E. W. Meijer, Chem.-Eur. J., 2002, 8, 4470.

15 A. Gadisa, W. Mammo, L. M. Andersson, S. Admassie, F. Zhang, M. R. Andersson and O. Inganäs, Adv. Funct. Mater., 2007, 17, 3836.

${ }_{55} 16$ M. P. O'Neil, M. P. Niemczyk, W. A. Svec, D. Gosztola, G. L. Gaines, III and M. R. Wasielewski, Science, 1992, 257, 63.

17 S. J. K. Pond, M. Rumi, M. D. Levin, T. C. Parker, D. Beljonne, M. W. Day, J.-L. Bredas, S. R. Marder and J. W. Perry, J. Phys. Chem. $A, 2002, \mathbf{1 0 6}, 11470$.

6018 P. D. W. Boyd and C. A. Reed, Acc. Chem. Res., 2005, 38, 235.

19 F. D'Souza and O. Ito, Chem. Commun., 2009, 4913.

20 S. Campidelli, C. Sooambar, E. Lozano Diz, C. Ehli, D. M. Guldi and M. Prato, J. Am. Chem. Soc., 2006, 128, 12544.

21 T. Palacin, H. L. Khanh, B. Jousselme, P. Jegou, A. Filoramo, C.

65 Ehli, D. M. Guldi and S. Campidelli, J. Am. Chem. Soc., 2009, 131, 15394.
22 H. Imahori, Y. Sekiguchi, Y. Kashiwagi, T. Sato, Y. Araki, O. Ito, H. Yamada and S. Fukuzumi, Chem.-Eur. J., 2004, 10, 3184.

23 H. Zhao, Y. Zhu, C. Chen, L. He and J. Zheng, Carbon, 2012, 50, 4894.

24 N. Karousis, R. M. Papi, A. Siskos, P. Vakalopoulou, P. Glezakos, Y. Sarigiannis, G. Stavropoulos, D. A. Kyriakidis and N. Tagmatarchis, Carbon, 2009, 47, 3550.

25 L. Bahr and J. M. Tour, Chem. Mater., 2001, 13, 3823.

7526 H. N. Yehia, R. K. Draper, C. Mikoryak, E. K. Walker, P. Bajaj, I. H. Musselman, M. C. Daigrepont, G. R. Dieckmann and P. Pantano, Journal of Nanobiotechnology, 2007, 5, 1.

27 A. Midya, V. Mamidala, J.-X. Yang, P. K. L. Ang, Z.-K. Chen, W. Ji and K. P. Loh, Small, 2010, 6, 2292.

8028 T. Umeyama, J. Mihara, H. Hayashi, N. Kadota, V. Chukharev, N. V. Tkachenko, H. Lemmtyinen, K. Yoshida, S. Isoda and H. Imahori, Chem. Commun., 2011, 47, 11781.

29 N. Karousis, A. S. D. Sandanayaka, T. Hasobe, S. P. Economopoulos, E. Sarantopoulou and N. Tagmatarchis, J. Mater. Chem., 2011, 21, 109.

30 D. Paolucci, M. M. Franco, M. Iurlo, M. Marcaccio, M. Prato, F. Zerbetto, A. Penicaud, and F. Paolucci, J. Am. Chem. Soc., 2008, 130, 7393.

31 Y. Tanaka, Y. Hirana, Y. Niidome, K. Kato, S. Saito, and N. Nakashima, Angew. Chem. Int. Ed., 2009, 48, 7655.

32 D. Ehli, C. Oelsner, D. M. Guldi, A. Mateo-Alonso, M. Prato, C. Schmidt, C. Backes, F. Hauke, and A. Hirsch, Nat. Chem., 2009, 1, 243.

33 A. S. D. Sandanayaka, E. Maligaspe, T. Hasobe, O. Ito, and F. D'Souza, Chem. Commun., 2010, 46, 8749.

34 F. D'Souza, S. K. Das, M. E. Zandler, A. S. D. Sandanayaka, and O. Ito, J. Am. Chem. Soc. 2011, 133, 19922. 